\title{
Greske og latinske ord i norsk
}

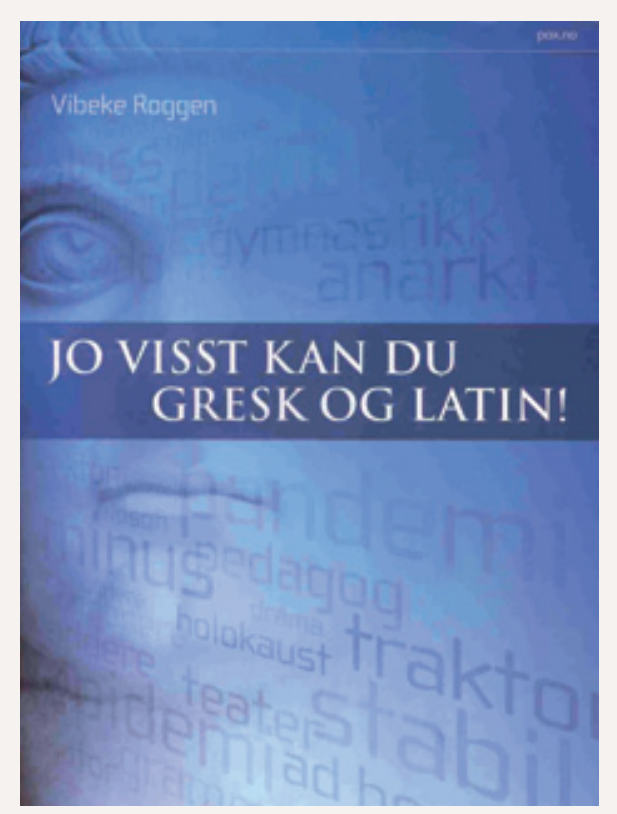

Interessen for språk er stor i vårt lille land. Fjernsynsserien Typisk norsk ble en suksess. Radioprogrammet Språkteigen sendes ukentlig på NRK P2. Per Egil Hegges språkspalte i Aftenposten leses av mange, og den nylig avgåtte språkrådsdirektøren Sylfest Lomheim er blitt rikskjendis. Og Tidsskriftets språkspalte har vist seg levedyktig gjennom 20 år (1). Årlig publiseres det mange bøker om ulike sider av språket vårt. To av årets utgivelser er av særlig interesse for medisinere.

\section{Den klassiske språkhistorien}

Vibeke Roggen er førsteamanuensis i latin ved Universitetet i Oslo og har skrevet flere lærebøker i latin. Hennes påstand - at alle kan mer gresk og latin enn de selv tror - er dristig. I hvert fall er det vist at latinkunnskapen blant norske leger er ganske skrøpelig. Riktignok bruker vi mange ord med klassiske røtter, men ordformene og bokstaveringen er ofte grammatikalsk ukorrekt (2).

Det er mye språkhistorie hos Roggen, og store deler av Jo visst kan du gresk og latin! handler faktisk om Romerrikets historie. Latin ble et verdensspråk pga. romernes militære og administrative suksess. Og, kanskje mer overraskende, latinen beholdt sin posisjon lenge etter Romerrikets fall i 476. Fra rundt år 600 var latin ikke lenger et morsmål, men måtte læres av alle som skulle bruke det. Likevel sto latinen meget sterkt i mer enn tusen år etterpå. Latin var faktisk offisielt språk i Polen til 1795 og i Ungarn til 1844!

Antikkens latin lånte mange ord fra gresk, påpeker Roggen. Den greske kul-
Vibeke Roggen

Jo visst kan du gresk og latin!

243 s, tab. Oslo: Pax, 2010.

Pris NOK 349

ISBN 978-82-530-3275-7

Oskar Fjeld

Klassiske røtter

Greske og latinske ord i norsk. $155 \mathrm{~s}$.

Fredrikstad: Faglitterært Forlag, 2010.

Pris NOK 300.

Kan bestilles fra forlaget: pertlars@online.no

ISBN 978-82-998370-1-9

turen var mer avansert og brakte inn

i latinen ord fra kultur og vitenskap.

Store deler av Roggens verk minner om en lærebok i latin med alle sine kasus og deklinasjoner. Det er egne kapitler om seksuallivet på klassiske språk og om kristendommens vokabular, men overraskende lite å finne om medisinske ord og uttrykk. Ett unntak er forklaringen på «delirium», som kommer av det latinske «lira» (plogfure) og «de-», som innebærer et avvik fra den. «Delirare» er «å avvike fra den rette plogfuren», i overført betydning «å være gal».

Bakerst er det et register over ord som er forklart i teksten - nesten 1000 ord i norsk som kommer fra klassiske språk. Men også her er det få medisinske termer å finne.

\section{Ordtabellene}

De medisinske innslagene er faktiske flere i den langt tynnere Klassiske røtter fra historikeren og filologen Oskar Konrad Fjeld (1911-2009). Fjeld, kjent for mange som lektor ved Oslo katedralskole gjennom 20 år, har samlet lånord i norsk fra gresk og latin i en mer tabellarisk form. Ordene er gruppert etter betydningen, forsynt med sin klassiske opprinnelse og forklart på norsk. I boken, som inneholder ca. 3700 lånord, viser han hvordan gresk og latin har preget, og fortsatt preger, norsk språk.

En stor del av lånordene har medisinsk betydning. Fjeld gir en god oversikt over nettopp det. Riktignok er det uvant å se placebo forklart som «medisin for å berolige» og se «læren om barnesykdommer» kalt pediatrikk, men likevel.

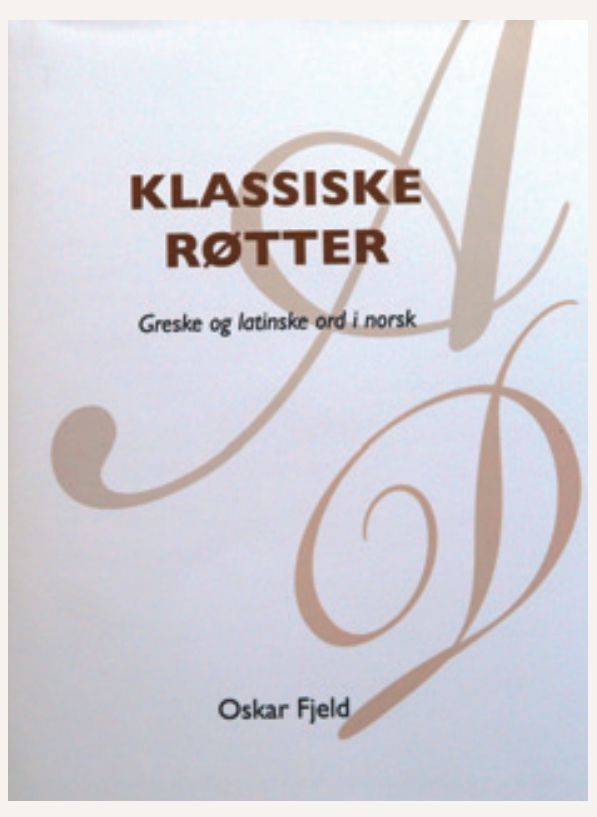

Den største delen av lånordene i norsk hører til vårt allmenne vokabular. Visste du at «kemner» har sin opprinnelse i det latinske «camera», eller at en nestor i faget har sitt navn etter Nestor, eldste høvding i Troja?

\section{Medisinsk fagspråk}

Medisinsk fagspråk har et internasjonalt preg, nettopp pga. det store innslaget av greske og latinske ord. De fleste leger behersker dette fagspråket godt, selv om vi ikke alltid vet hvilke ord som har greske og hvilke som har latinske røtter. Men mer kunnskap er aldri å forakte, heller ikke på det språklige området. Minst like viktig som at innsikt $i$ latin og gresk kan forbedre vårt fagspråk, er gleden av å lære noe nytt, annerledes og uventet. Begge disse bøkene tilbyr slik kunnskap - i to ganske ulike former og formater.

Språk kan divertere [lat.: underholde].

Quod bonum, felix faustumque sit [lat.: måtte det bringe glede, hell og lykke].

\section{Magne Nylenna}

magne.nylenna@helsebiblioteket.no

Helsebiblioteket

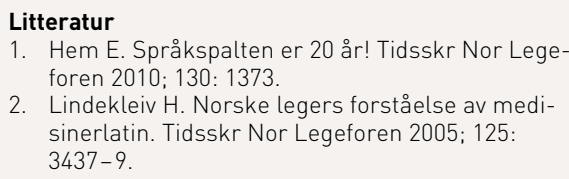

1. Hem E. Språkspalten er 20 år! Tidsskr Nor Legeforen 2010; 130: 1373

2. Lindekleiv H. Norske legers forståelse av medisinerlatin. Tidsskr Nor Legeforen 2005; 125: 3437-9. 